\title{
PERSEPSI DOSEN DAN MAHASISWA TERHADAP SISTEM INFORMASI AKADEMIK DALAM MENUNJANG PROSES PELAPORAN HASIL STUDI MAHASISWA UNDIKSHA
}

\author{
I Kadek Handi Putra Widya Aksara \\ Jurusan Pendidikan Ekonomi \\ Universitas Pendidikan Ganesha \\ Singaraja, Indonesia \\ e-mail: putra_aksara@yahoo.co.id
}

\begin{abstract}
Abstrak
Penelitian ini bertujuan untuk menyatakan tentang persepsi dosen dan mahasiswa terhadap sistem informasi akademik dalam menunjang proses pelaporan hasil studi mahasiswa Undiksha. Penelitian ini menggunakan rancangan penelitian deskriptif. Data dikumpulkan dengan metode dokumentasi dan angket. Data diuji menggunakan analisis deskriptif dengan bantuan aplikasi pengolahan data SPSS 16 for Windows dan Microsoft excel. Hasil penelitian menunjukan bahwa persepsi dosen dan mahasiswa terhadap sistem informasi akademik dalam menunjang proses pelaporan hasil studi mahasiswa Undiksha sudah baik atau positif. Walaupun masih terdapat beberapa kekurangan seperti akses informasi yang masih lambat dan informasi tentang mahasiswa perlu ditambah agar cakupannya lebih luas sehingga dapat menunjang proses pelaporan hasil studi mahasiswa Undiksha.
\end{abstract}

Kata Kunci: persepsi, Sistem Informasi Akademik

\section{Abstract}

This study aims to state about the perception of lecturers and students to the academic information system in supporting the reporting process of the study results of Undiksha students. This research uses descriptive research design. Data were collected by documentation method and questionnaire. Data were tested using descriptive analysis with the SPSS 16 for Windows and Microsoft excel data processing applications. The results showed that the perception of lecturers and students to the academic information system in supporting the reporting process of the study results of Undiksha students have been good or positive. Although there are still some shortcomings such as access to information that is still slow and information about the students need to be added to the wider scope so that it can support the reporting process of Undiksha student study.

Keywords: perception, Academic Information System

\section{PENDAHULUAN}

Perkembangan teknologi yang semakin maju saat ini berdampak positif bagi kehidupan manusia. Perkembangan teknologi ini dimanfaatkan dalam berbagai bidang baik dalam bidang pendidikan maupun non pendidikan. Dalam dunia pendidikan, teknologi dimanfaatkan untuk menunjang kegiatan operasional dalam rangka meningkatkan kinerja dan memperoleh keunggulan kompetitif. McKeown dalam Suyanto (2005:3) menyatakan "teknologi informasi merujuk pada seluruh bentuk teknologi yang digunakan untuk menciptakan, menyimpan, mengubah dan menggunakan informasi dalam segala bentuknya".

$$
\text { Dalam teknologi informasi, }
$$
informasi yang diciptakan maupun digunakan harus memiliki karakteristik dan kualitas. Tata Sutabri (2012:33) menyatakan "kualitas dari suatu informasi tergantung dari tiga hal, yaitu informasi harus akurat (accurate), tepat waktu (timeliness), dan relevan (relevance)". Teknologi informasi pada bidang layanan administrasi akademik di perguruan tinggi menjadi suatu 
kebutuhan, bukan hanya sekedar prestise atau lifestyle manajemen pendidikan tinggi modern. Yakub (2012:13) menyatakan "untuk tiap-tiap tingkatan manajemen dengan kegiatan yang berbeda, dibutuhkan informasi dengan karakteristik yang berbeda pula". Karakteristik dari informasi yaitu. Pertama kepadatan informasi, untuk manajemen tingkat bawah karakteristik informasinya adalah terperinci dan kurang padat karena digunakan untuk pengendalian operasi. Sedangkan untuk manajemen yang lebih tinggi tingkatannya, mempunyai karakteristik informasi yang semakin tersaring, lebih ringkas dan padat. Kedua luas informasi, manajemen tingkat bawah karakteristik informasinya adalah terfokus pada suatu masalah tertentu, karena digunakan oleh manajer bawah yang mempunyai tugas khusus. Sedangkan untuk manajemen yang lebih tinggi tingkatannya mempunyai karakteristik informasi yang semakin luas, karena manajemen atas berhubungan dengan masalah yang luas. Ketiga frekuensi informasi, manajemen tingkat bawah frekuensi informasi yang diterimanya adalah rutin, karena digunakan oleh manager bawah yang mempunyai tugas terstruktur dengan pola yang berulang-ulang dari waktu ke waktu. Manajemen yang lebih tinggi tingkatannya frekuensi informasinya adalah tidak rutin, karena manajemen tingkat atas berhubungan dengan pengambilan keputusan tidak terstruktur yang pola dan waktunya tidak jelas. Keempat akses informasi, level bawah membutuhkan informasi yang periodenya berulang-ulang sehingga dapat disediakan oleh bagian sistem informasi yang memeberikan dalam bentuk laporan periodik. Dengan demikian akses informasi tidak dapat secara online tetapi dapat secara off line. Sebaliknya untuk level tinggi, periode informasi yang dibutuhkan tidak jelas sehingga manajer tingkat atas perlu disediakan akses online untuk mengambil informasi kapan pun mereka membutuhkan. Kelima waktu informasi, manajemen tingkat bawah, informasi yang dibutuhkan adalah informasi historis, karena digunakan dalam pengendalian operasi yang memeriksa tugas rutin yang sudah terjadi. Untuk manajemen tingkat tinggi waktu informasi lebih ke masa depan berupa informasi prediksi karena digunakan untuk pengambilan keputusan strategik yang menyangkut nilai masa depan. Keenam sumber informasi, karena manajemen tingkat bawah lebih berfokus pada pengendalian internal perusahaan. Maka manajer tingkat bawah lebih memerlukan informasi dengan data yang bersumber dari internal perusahaan sendiri. Manajer tingkat atas lebih berorientasi pada masalah perencanaan strategik yang berhubungan dengan lingkungan luar perusahaan. Karena itu membutuhkan informasi dengan data yang bersumber pada eksternal perusahaan.

Universitas Pendidikan Ganesha (Undiksha) sebagai salah satu perguruan tinggi yang mempunyai komitmen untuk memanfaatkan serta mengikuti perkembangan teknologi informasi untuk meningkatkan pelayanan yang didukung sistem informasi kepada para pengguna jasa pendidikan. Sistem informasi yang digunakan Undiksha dalam meningkatkan pelayaanan kepada mahasiswa dan dosen adalah sistem informasi akademik. Menurut Etin (2011) secara spesifik sistem informasi akademik memiliki beberapa karakter yang cukup luas yaitu (1) sistem informasi akademik bermakna sebagai pendekatan-pendekatan dalam melakukan proses manajemen, (2) komputer hanya merupakan komponen atau alat bukan fokus sentral dari sistem informasi akademik, (3) pimpinan berperan aktif dalam rangka sistem sebagai pengguna informasi bukan sebagai tenaga teknis ataupun operator computer dan 4) esensi sistem informasi administrasi terletak pada sistem terpadu dan sistem terencana, bukan hanya urusan mekanisme pengolahan data.

Sistem informasi akademik Undiksha merupakan sistem informasi 
yang dikembangkan untuk mempermudah pengelolaan data akademik bagi mahasiswa dan dosen. Pengelolaan data akademik mahasiswa berupa Kartu Hasil Studi (KHS), Kartu Rencana Studi (KRS) dan pengelolaan data akademik bagi dosen yaitu cara memasukan nilai dan mengisi agenda perkuliahan. Melalui sistem informasi akademik Undiksha pengguna dapat melihat informasi mahasiswa, dosen, jurusan, fakultas secara online melalui jaringan internet. Sistem informasi akademik Undiksha juga bisa diguakan oleh dosen sebagai alat untuk melihat perkembangan peserta didik, sehingga bisa dijadikan sebagai pertimbangan oleh dosen dalam memberikan masukan kepada mahasiswa dalam menyusun KRS. Sedangkan bagi mahasiswa sistem informasi akademik Undiksha digunakan untuk mempermudah dalam penyusunan KRS dan untuk melihat nilai melalui KHS online. Dengan adanya sistem informasi akademik ini terjadi sedikit perubahan terhadap mekanisme pengelolaan data akademik, bagi dosen yang dulunya dalam menginput nilai dilakukan oleh pihak Pusat Komputer (Puskom) dan sekarang menuntut para dosen untuk menginput nilai mahasiswa kedalam sistem informasi akademik dengan tenggang waktu yang sudah ditentukan oleh Puskom. Batas penginput nilai yang dilakukan oleh dosen diberikan waktu selama 14 hari oleh puskom.

Namun dalam pelaksanaanya, pemanfaatan sistem informasi akademik oleh dosen maupun mahasiswa masih menemui berbagai masalah. Berdasarkan observasi awal masalah yang ditemui oleh peneliti yaitu ketika mahasiswa mengunduh nilai mata kuliah yang diprogramkan belum muncul dalam sistem informasi akademik dan tidak seperti yang dijadwalkan sebelumnya. Salah satu penyebab dari masalah ini adalah pada umumnya dosen mengunggah nilai pada batas hari terakhir penjadwalan yang mengakibatkan kinerja sistem lambat atau sistem belum mampu bekerja optimal ketika dosen mengunggah nilai pada waktu bersamaan, masalah ini terkait dengan pengaturan dan kapasitas sistem informasi akademik Undiksha. Selain itu setelah data diinput dan divalidasi maka apabila ada perubahan, lalu untuk merubahnya memerlukan proses yang panjang. Untuk mengkoreksi atau merubah data, dosen harus melakukan konfirmasi dan membuka validasi data kepuskom agar bisa merubah nilai yang salah. Atas permasalahan di atas, maka penulis tertarik melakukan penelitian tentang persepsi dosen dan mahasiswa terhadap sistem informasi akademik dalam menunjang proses pelaporan hasil studi mahasiswa Undiksha.

Demi menghasilkan layanan akademik yang baik dalam menunjang proses pelaporan hasil studi mahasiswa, maka sangat perlu untuk mengetahui persepsi dari pengguna layanan itu sendiri. Walgito (2002:87) menyatakan "persepsi merupakan suatu proses yang didahului oleh proses pengindraan yaitu proses diterimanya stimulus oleh individu melalui alat indra atau juga disebut proses sensoris". Persepsi adalah proses yang menyangkut masuknya pesan atau informasi ke dalam otak manusia (Slameto, 2010). G.Sohiffman dan Leslie Lazar Kanuk (dalam Muflih, 2006:92) menyatakan "persepsi diartikan sebagai proses yang dilakukan individu untuk memilih, mengatur, dan menafsirkan kedalam gambar yang berarti dan masuk akal mengenai dunia". Krech (dalam Rakhmat, 2007:51) menyatakan bahwa "persepsi adalah suatu kognitif dan kompleks dan menghasilkan gambar yang unik tentang kenyataan yang barangkali sangat berbeda dari kenyataannya. Sedangkan menurut Robbins (2003), persepsi dapat didefinisikan sebagai suatu proses yang ditempuh individuindividu untuk mengorganisasikan dan menafsirkan kesan indera mereka agar memberi makna kepada lingkungan mereka. Apa yang dipersepsikan seseorang dapat berbeda dari kenyataan yang objektif. 
Persepsi merupakan kemampuan untuk memahami dan menginterpretasikan lingkungan secara akurat. Dengan demikian persepsi merupakan proses memaknai atau menginterpretasikan stimulus. Makna interpretasi tersebut dibuat individu berdasarkan realita objektif dan pengetahuan yang dimilikinya serta bagaimana individu mengorganisasikan stimulus. Oleh sebab itu individu tidak dapat mempersepsi suatu stimulus (objek) bila ia tidak memiliki pengetahuan sebelumnya tentang objek. Menurut Walgito (2002) persepsi dapat terjadi melalui beberapa tahap yaitu. (1) Tahap pertama yaitu proses fisik. Suatu objek atau sasaran menimbulkan stimulus, selanjutnya stimulus mengenai alat indra (reseptor). (2) Tahap kedua yaitu proses fisiologis. Proses fisiologis merupakan proses diteruskannya stimulus yang diterima oleh alat indra melalui syaraf sensorik ke otak. (3) Tahap ketiga yaitu proses psikologis. Proses psikologis merupakan proses timbulnya kesadaran individu menyadari apa yang dilihat, apa yang didengar atau apa yang diraba berdasarkan stimulus yang diterimanya.

(4) Tahap ke empat yaitu hasil yang diperoleh dari proses persepsi yaitu berupa tanggap dan prilaku.

Respon individu baik dalam bentuk tanggapan maupun perilaku sebagai akibat dari persepsi dapat diambil oleh individu dengan berbagai macam bentuk. Stimulus yang akan mendapatkan respon dari individu tergatung pada perhatian individu yang bersangkutan. Agar stimulus dapat dipersepsi, maka stimulus harus cukup kuat dan jelas sehingga stimulus dapat dipersepsi oleh individu.

Persepsi tersebut dipengaruhi oleh beberapa faktor seperti (1) faktor internal meliputi perasaan, sikap dan kepribadian individu, prasangka, keinginan atau harapan, perhatian (fokus), proses belajar, keadaan fisik, gangguan kejiwaan, nilai dan kebutuhan juga minat, dan motivasi (2) Faktor eksternal meliputi latar belakang keluarga, informasi yang diperoleh, pengetahuan dan kebutuhan sekitar, intensitas, ukuran, keberlawanan, pengulangan gerak, hal-hal baru dan familiar atau ketidak asingan suatu objek.

Menurut Robbins (2009) ada tiga faktor yang mempengaruhi terbentuknya persepsi. Ketiga faktor tersebut yaitu. (1) Pelaku persepsi (perceiver/orang yang membentuk persepsi itu sendiri), khususnya kondisi intren. Ketika seorang individu melihat sebuah target dan berusaha menginterpretasikan yang di lihat, maka interpretasi tersebut pasti dipengaruhi oleh karakteristik pribadi dari pelaku persepsi. Karakteristik pribadi dari pelaku yang mempengaruhi persepsi yaitu. a) Sikap merupakan reaksi atau respon individu terhadap stimulus atau objek. Sikap mempengaruhi persepsi individu terhadap objek tergantung pada individu sendiri untuk suka atau tidak terhadap objek. b) Kebutuhan merupakan keinginan individu unuk menemukan jawaban yang sesuai dengan dirinya. Kebutuhan dapat mempengaruhi persepsi tergantung pada besar atau tidaknya keinginan individu mencari objek-objek atau pesan yang sesuai dengan keinginan dirinya.

c) Minat adalah perhatian terhadap objek yang menarik. Minat mempengaruhi persepsi, tergantung pada kecenderungan seseorang untuk memperhatikan stimulus atau objek yang menarik agar dapat memperoleh makna dari informasi. d) Motivasi adalah semua gerak, alasan-alasan atau dorongan dalam diri individu yang menyebabkan individu berbuat sesuatu. Motivasi berpengaruh terhadap persepsi individu jika ada dorongan atau alsan individu terhadap objek. e) Harapan adalah keinginan seseorang terhadap objek mengenai hal yang disukai dan diharapkan. Jadi harapan akan mempengaruhi persepsi individu terhadap objek jika objek tersebut disukai dan diharapkan. f) Pengalaman merupakan peristiwa yang dialami seseorang. Hal ini berarti pengalaman yang dialami sendri oleh individu akan lebih kuat dan sulit dilupakan 
dibandingkan dengan melihat pengalamnan orang lain karen individu telah membuktikan secara langsung. Pengalaman mempengaruhi persepsi individu terhadap objek tergantung pada peristiwa yang pernah dialami. (2) Karakteristik objek baik berupa benda maupun peristiwa. Karakteristik target atau objek bisa mempengaruhi persepsi baik karena individu memiliki kecendrungan dalam mengelompokan hal-hal yang dekat sehingga dianggap sama, gerakan individu yang dapat memberikan perhatian berbeda dan hal baru yang dapat memberikan kesan atau arti yang berbeda terhadap pelaku persepsi. (3) Konteks dari situasi akan menyebabkan persepsi individu terhadap objek dapat berubah bergantung pada situasi. Misalnya situasi proses belajar mengajar di area terbuka pada hari libur akan berbeda dengan situasi belajar mengajar di area lingkungan sekolah (di kelas) pada hari efektif.

Persepsi dari dosen dan mahasiswa bisa dikatakan baik apabila memperoleh nilai atau tanggapan yang positif dari dosen dan mahasiswa, sedangkan dikatakan buruk apabila memperoleh nilai negatif dari dosen dan mahasiswa. Robbins (2002:14) menyatakan "persepsi positif merupakan penilaian individu terhadap suatu objek atau informasi dengan pandangan yang positif atau sesuai dengan yang diharapkan dari objek yang dipersepsikan atau dari aturan yang ada, sedangkan persepsi negatif merupakan persepsi individu terhadap objek atau informasi tertentu dengan pandangan yang negatif, berlawanan dengan yang diharapkan dari objek yang dipersepsikan atau dari aturan yang ada". Penyebab munculnya persepsi negatif seseorang dapat muncul karena adanya ketidakpuasan individu terhadap objek yang menjadi sumber persepsinya, adanya ketidaktahuan individu serta tidak adanya pengalaman inidvidu terhadap objek yang dipersepsikan dan sebaliknya, penyebab munculnya persepsi positif seseorang karena adanya kepuasan individu terhadap objek yang menjadi sumber persepsinya, adanya pengetahuan individu, serta adanya pengalaman individu terhadap objek yang dipersepsikan.

\section{METODE}

Penelitian ini dilakukan pada Universitas Pendidikan Ganesha (Undiksha). Penelitian ini merupakan penelitian deskriptif. Adapun penelitian ini mendiskripsikan tentang persepsi dosen dan mahasiswa terhadap sistem informasi akademik dalam menunjang proses pelaporan hasil studi mahasiswa Undiksha, diukur melalui tiga indikator persepsi menurut Robbins (2009) yaitu pelaku persepsi, karakteristik objek dan konteks situasi. Subjek dalam penelitian ini adalah dosen dan mahasiswa Undiksha. Sedangkan objek penelitian ini adalah persepsi dosen dan mahasiswa terhadap sistem informasi akademik dalam menunjang proses pelaporan hasil studi mahasiswa Undiksha.

Berdasarkan jenisnya, data yang digunakan dalam penelitian ini adalah data kuantitatif. Data kuantitatif adalah data yang dapat dihitung dan berupa angka-angka. Data kuantitatif dalam penelitian ini yaitu skor jawaban responden mengenai persepsi dosen dan mahasiswa terhadap sistem informasi akademik dalam menunjang proses pelaporan hasil studi mahasiswa Undiksha. Berdasarkan sumbernya, sumber data yang digunakan dalam penelitian ini adalah data primer. Data primer dalam penelitian ini yaitu skor hasil kuesioner tentang persepsi dosen dan mahasiswa terhadap sistem informasi akademik dalam menunjang proses pelaporan hasil studi mahasiswa Undiksha yang diperoleh melalui penyebaran kueisoner yang diberikan kepada dosen dan mahasiswa Undiksha sebagai responden.

Populasi dalam penelitian ini adalah dosen Undiksha sebanyak 457 orang dan mahasiswa Undiksha sebanyak 10.326 orang, karena populasi yang ada jumlahnya besar 
maka peneliti menggunakan sampel. Teknik sampling yang digunakan dalam penelitian ini adalah stratified random sampling dengan alokasi proporsional karena anggota populasi di anggap heterogen berdasarkan karakteristik dari beberapa fakultas yang ada di Undiksha. Sampel dosen sebesar 90 dosen dan sempel mahasiswa sebesar 109 mahasiswa. Untuk memperoleh data yang diinginkan dalam penelitian ini, peneliti menggunakan metode pengumumpulan menggunakan instrument kuesioner dan metode dokumentasi. Kuesioner terdiri dari daftar pernyataan yang telah disusun untuk memperoleh data mengenai persepsi dosen dan mahasiswa terhadap sistem informasi akademik dalam menunjang proses pelaporan hasil studi mahasiswa Undiksha. Dari jawaban daftar pernyataan yang diajukan pada responden diolah dengan skala likert, skala yang berisi lima tingkat preferensi jawaban yaitu sangat setuju, setuju, ragu-ragu, tidak setuju dan sangat tidak setuju. Metode dokumentasi berarti cara mengumpulkan data dengan mencatat data-data yang sudah ada. Metode dokumentasi yang dibutuhkan dalam penelitian ini merupakan dokumen resmi internal dari Undiksha yang dapat berupa data jumlah dosen, mahasiswa, dan dokumen-dokumen lain yang mendukung, dimana menurut Moleong dalam Wadi (2006:98), "dokumen internal dapat berupa memo, pengumuman, instruksi, aturan suatu lembaga masyarakat yang digunakan dalam lingkungan sendiri".

Teknik analisa data yang digunakan dalam penelitian ini adalah teknik analisisa deskriptif. Analisis deskriptif merupakan bentuk analisis data penelitian untuk menginterprestasi manusia, suatu objek, suatu set kondisi, suatu sistem pemikiran ataupun suatu kelas peristiwa pada masa sekarang (Nazir, 2003). Untuk mempermudah analisis data persepsi dosen dan mahasiswa terhadap sistem informasi akademik dalam menunjang proses pelaporan hasil studi mahasiswa Undiksha, penulis menggunakan aplikasi pengolahan data SPSS 16.0 for windows dan Microsoft excel. Dari hasil pengolahan data dan analisis data dengan menggunakan SPSS 16.0 for windows dan Microsoft excel kemudian dicocokkan dengan kriteria deskriptif yang dikelompokan dalam dua kategori yaitu positif dan negatif. Jika rata-rata nilai yang diperoleh lebih dari sama dengan rata-rata nilai dari semua butir pernyataan maka dikatakan positif, namun jika rata-rata nilai kurang dari rata-rata nilai dari semua butir pernyataan maka dinyatakan negatif (Arikunto, 2006).

\section{HASIL DAN PEMBAHASAN Hasil}

Persepsi dosen terhadap sistem informasi akademik dalam menunjang proses pelaporan hasil studi mahasiswa Undiksha dapat digambarkan dari pelaku persepsi, karakteristik objek dan konteks situasi. Persepsi dosen terhadap sistem informasi akademik dalam menunjang proses pelaporan hasil studi mahasiswa Undiksha dilihat dari indikator pelaku persepsi yang mencakup sikap, kebutuhan, minat dan motivasi sudah positif. Akan tetapi pelaku persepsi yang mencakup harapan dan pengalaman masih negatif. Data dapat dilihat pada tabel 1.

Tabel 1. Persepsi Dosen Dilihat dari Indikator Pelaku Persepsi

\begin{tabular}{|c|c|c|c|c|c|c|c|c|c|c|}
\hline \multirow{2}{*}{ No. } & \multirow{2}{*}{ Sub Indikator } & \multicolumn{5}{|c|}{ Rating } & \multirow{2}{*}{$\begin{array}{c}\text { Jumlah } \\
\text { Responden }\end{array}$} & \multirow{2}{*}{$\begin{array}{l}\text { Jumlah } \\
\text { Nilai }\end{array}$} & \multirow{2}{*}{$\begin{array}{l}\text { Rata-Rata } \\
\text { Nilai }\end{array}$} & \multirow[b]{2}{*}{ Kategori } \\
\hline & & 5 & 4 & 3 & 2 & 1 & & & & \\
\hline 1 & Sikap & 41 & 40 & 0 & 9 & 0 & 90 & 383 & 4.26 & Positif \\
\hline 2 & Kebutuhan & 10 & 61 & 16 & 3 & 0 & 90 & 34 & 3.8 & Positif \\
\hline 3 & Minat & 18 & 61 & 8 & 3 & 0 & 90 & 364 & 4.0 & Positif \\
\hline 4 & Motivasi & 20 & 37 & 32 & 1 & 0 & 90 & 346 & $3 . \varepsilon$ & Positif \\
\hline 5 & Harapan & 2 & 55 & 19 & 14 & 0 & 90 & 315 & 3.50 & Negatif \\
\hline 6 & Pengalaman & 10 & 36 & 36 & 8 & 0 & 90 & 318 & 3.53 & Negatif \\
\hline
\end{tabular}


Persepsi dosen terhadap sistem informasi akademik dalam menunjang proses pelaporan hasil studi mahasiswa Undiksha dilihat dari indikator karakteristik objek yang mencakup kepadatan informasi, frekuensi informasi, akses informasi, waktu informasi dan sumber informasi sudah positif, hanya dari segi luas informasi masih negatif. Data dapat dilihat pada tabel

Tabel 2. Persepsi Dosen Dilihat dari Indikator Karakteristik Objek

\begin{tabular}{|c|c|c|c|c|c|c|c|c|c|c|}
\hline \multirow{2}{*}{ No. } & \multirow{2}{*}{ Sub Indikator } & \multicolumn{5}{|c|}{ Rating } & \multirow{2}{*}{$\begin{array}{c}\text { Jumlah } \\
\text { Responden }\end{array}$} & \multirow{2}{*}{$\begin{array}{l}\text { Jumlah } \\
\text { Nilai }\end{array}$} & \multirow{2}{*}{$\begin{array}{l}\text { Rata-Rata } \\
\text { Nilai }\end{array}$} & \multirow{2}{*}{ Kategori } \\
\hline & & 5 & 4 & 3 & 2 & 1 & & & & \\
\hline 1 & Kepadatan Informasi & 17 & 63 & 8 & 2 & 0 & 90 & 365 & 4.06 & Positif \\
\hline 2 & Luas Informasi & 4 & 53 & 22 & 11 & 0 & 90 & 320 & 3.56 & Negatif \\
\hline 3 & Frekuensi Informasi & 14 & 63 & 11 & 2 & 0 & 90 & 359 & 3.99 & Positif \\
\hline 4 & Akses Informasi & 19 & 57 & 10 & 4 & 0 & 90 & 361 & 4.01 & Positif \\
\hline 5 & Waktu Informasi & 18 & 53 & 17 & 2 & 0 & 90 & 357 & 3.97 & Positif \\
\hline 6 & Sumber Informasi & 20 & 60 & 10 & 0 & 0 & 90 & 370 & 4.11 & Positif \\
\hline \multicolumn{7}{|c|}{ Persepsi dosen terhadap sistem } & \multicolumn{4}{|c|}{$\begin{array}{l}\text { informasi dan relevansi informasi sudah } \\
\text { positif. Akan tetapi konteks situasi yang } \\
\text { dilihat dari ketepatan waktu informasi } \\
\text { masih negatif. Data dapat dilihat pada }\end{array}$} \\
\hline
\end{tabular}

Tabel 3. Persepsi Dosen Dilihat dari Indikator Konteks Situasi

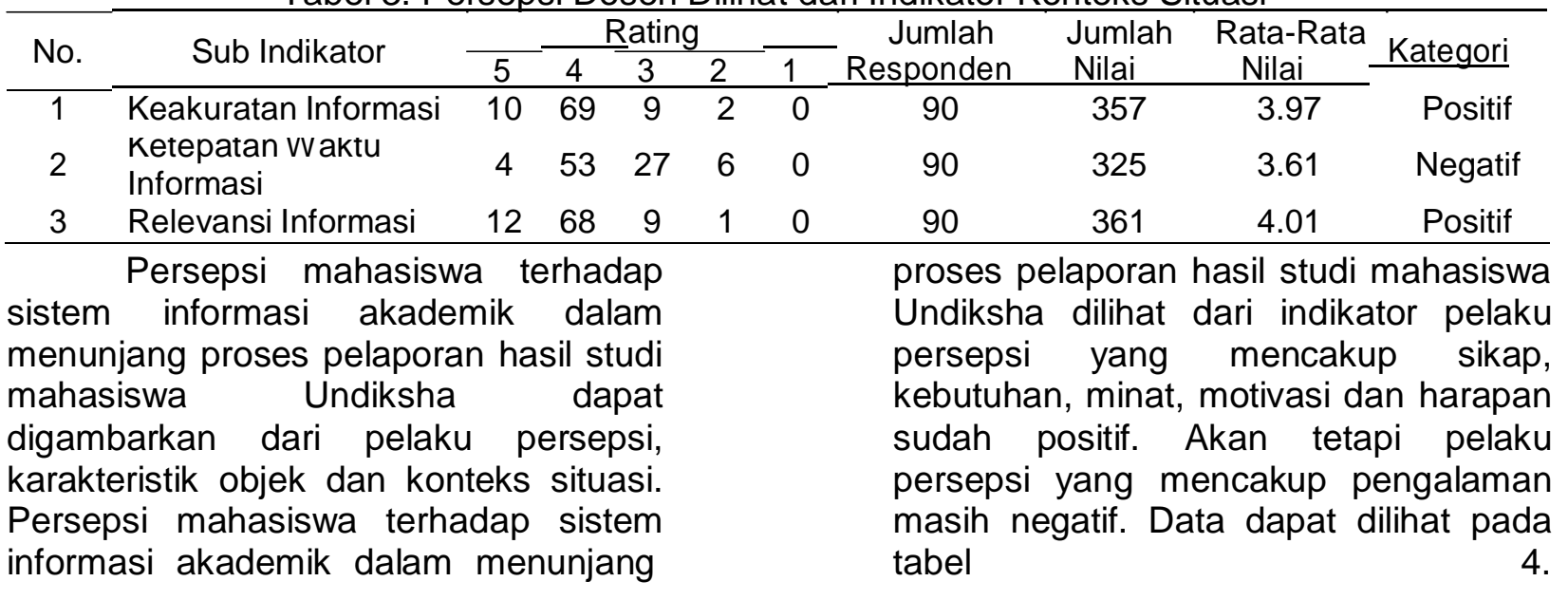

Tabel 4. Persepsi Mahasiswa Dilihat dari Indikator Pelaku Persepsi

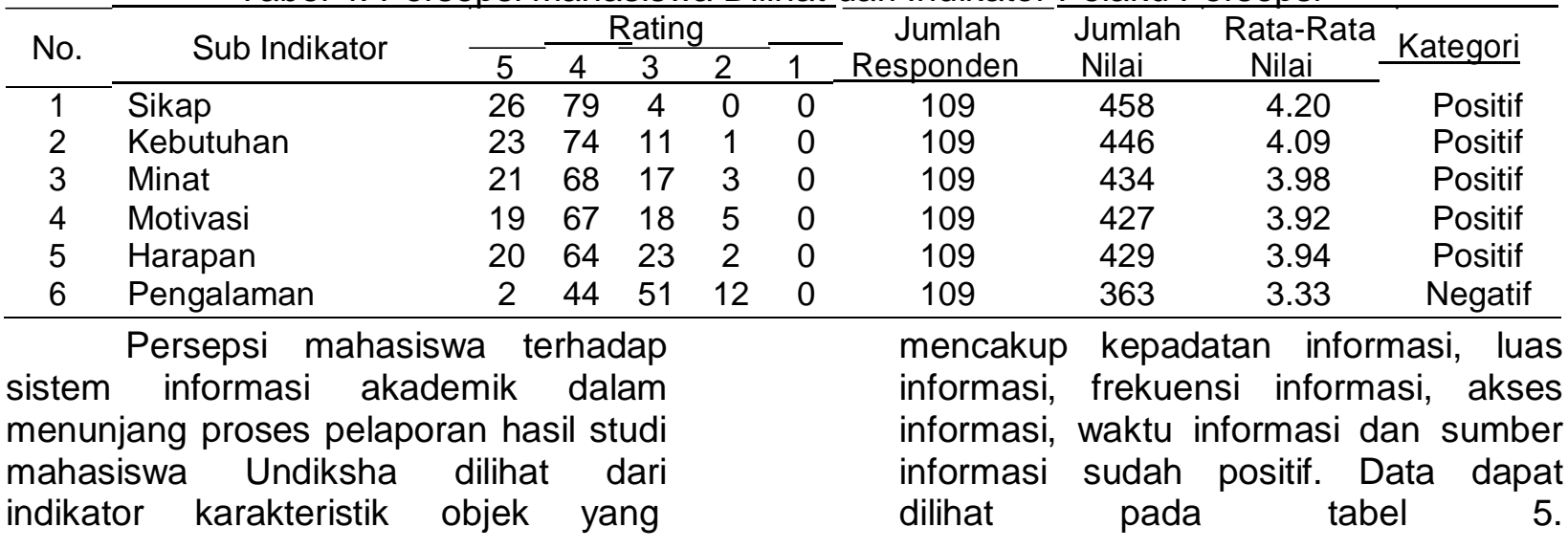


Tabel 5. Persepsi Mahasiswa Dilihat dari Indikator Karakteristik Objek

\begin{tabular}{|c|c|c|c|c|c|c|c|c|c|c|}
\hline \multirow{2}{*}{ No. } & \multirow{2}{*}{ Sub Indikator } & \multicolumn{5}{|c|}{ Rating } & \multirow{2}{*}{$\begin{array}{c}\text { Jumlah } \\
\text { Responden }\end{array}$} & \multirow{2}{*}{$\begin{array}{l}\text { Jumlah } \\
\text { Nilai }\end{array}$} & \multirow{2}{*}{$\begin{array}{c}\text { Rata-Rata } \\
\text { Nilai }\end{array}$} & \multirow{2}{*}{ Kategori } \\
\hline & & 5 & 4 & 3 & 2 & 1 & & & & \\
\hline 1 & Kepadatan Informasi & 28 & 73 & 7 & 1 & 0 & & & & Positif \\
\hline 2 & & 32 & 69 & 5 & 3 & 0 & & & & \\
\hline 3 & Frekuensi Informasi & 30 & 70 & 8 & 1 & 0 & & 456 & & ositif \\
\hline 4 & Aks & 29 & 71 & 7 & 2 & & & & & \\
\hline 5 & Wak & 31 & 67 & 11 & 0 & & & & 4. & \\
\hline 6 & Sumber Informasi & 33 & 65 & 8 & 3 & 0 & 109 & 455 & 4.17 & Positif \\
\hline \multicolumn{7}{|c|}{$\begin{array}{l}\text { Persepsi mahasiswa terhadap } \\
\text { informasi akademik dalam } \\
\text { jang proses pelaporan hasil studi }\end{array}$} & \multicolumn{4}{|c|}{$\begin{array}{l}\text { segi keakuratan informasi dan relevans } \\
\text { informasi sudah positif. Akan tetap } \\
\text { kontek situasi yang dilihat da }\end{array}$} \\
\hline
\end{tabular}

Tabel 6. Persepsi Mahasiswa Dilihat dari Indikator Konteks Situasi

\begin{tabular}{|c|c|c|c|c|c|c|c|c|c|c|}
\hline \multirow{2}{*}{ No. } & \multirow{2}{*}{ Sub Indikator } & \multicolumn{5}{|c|}{ Rating } & \multirow{2}{*}{$\begin{array}{c}\text { Jumlah } \\
\text { Responden }\end{array}$} & \multirow{2}{*}{$\begin{array}{l}\text { Jumlah } \\
\text { Nilai }\end{array}$} & \multirow{2}{*}{$\begin{array}{l}\text { Rata-Rata } \\
\text { Nilai }\end{array}$} & \multirow{2}{*}{ Kategori } \\
\hline & & 5 & 4 & 3 & 2 & 1 & & & & \\
\hline 1 & Keakuratan Informasi & 12 & 73 & 24 & 0 & 0 & 109 & 424 & 3.89 & Positif \\
\hline 2 & $\begin{array}{l}\text { Ketepatan Vvaktu } \\
\text { Informasi }\end{array}$ & 3 & 30 & 62 & 13 & 1 & 109 & 348 & 3.19 & Negatif \\
\hline 3 & Relevansi Informasi & 8 & 80 & 18 & 3 & 0 & 109 & 420 & 3.85 & Positif \\
\hline
\end{tabular}

Pembahasan

Persepsi dosen terhadap sistem informasi akademik dalam menunjang proses pelaporan hasil studi mahasiswa Undiksha dilihat dari indikator pelaku persepsi yang mencakup sikap, kebutuhan, minat dan motivasi secara umum sudah positif. Jadi dapat dikatakan bahwa seluruh dosen Undiksha memiliki persepsi yang baik dilihat dari segi sikap, kebutuhan, minat dan motivasi terhadap sistem informasi akademik dalam menunjang proses pelaporan hasil studi mahasiswa Undiksha. Bukan berarti secara umum positif menunjukan sistem informasi akademik tidak mempunyai masalah, namun dilihat dari harapan dan pengalaman masih negatif.

Persepsi dosen dilihat dari indikator karakteristik objek dan kontek situasi secara umum adalah positif dan hanya sebagian kecil dari sub indikator dari indikator tersebut yang masih negatif. Misalnya saja dari segi luasnya informasi dan ketepatan waktu informasi yang dibutuhkan dosen masih kurang sehingga proses pelaporan hasil studi mahasiswa Undiksha sedikit terkendala. Berdasarkan penjelasan di atas,

persepsi dosen terhadap sistem
informasi akademik dalam menunjang proses pelaporan hasil studi mahasiswa Undiksha sudah baik.

Persepsi mahasiswa terhadap sistem informasi akademik dalam menunjang proses pelaporan hasil studi mahasiswa Undiksha dilihat dari indikator pelaku persepsi yang mencakup sikap, kebutuhan, minat, motivasi dan harapan sudah positif. Jadi dapat dikatakan bahwa seluruh mahasiswa Undiksha memiliki persepsi yang baik dilihat dari segi sikap, kebutuhan, minat, motivasi dan harapan terhadap sistem informasi akademik dalam menunjang proses pelaporan hasil studi mahasiswa Undiksha, namun dilihat dari sub indikator pengalaman masih menunjukan hasil negatif, karena kurang cepatnya respon pengelola sistem informasi akademik dalam menangani keluhan mahasiswa. Begitu pula persepsi mahasiswa dilihat dari indikator karakteristik objek dan konteks situasi secara umum adalah positif dan hanya dari segi ketepatan waktu informasi yang masih negatif. Berdasarkan penjelasan di atas, persepsi mahasiswa terhadap sistem 
informasi akademik dalam menunjang proses pelaporan hasil studi mahasiswa Undiksha sudah baik.

Dari paparan di atas dapat dilihat persepsi dosen dan mahasiswa tentang sistem informasi akademik dalam menunjang proses pelaporan hasil studi mahasiswa Undiksha sudah baik, walaupun masih terdapat beberapa sub indikator dari masingmasing indikator yang masih negatif. Hal ini terjadi karena sistem informasi akademik Undiksha masih memiliki kelemahan, misalnya saat penggunaan sistem informasi akademik dilakukan bersama baik oleh dosen maupun mahasiswa mengakibatkan kinerja sistem lambat atau sistem belum mampu bekerja optimal sehingga terjadi keterlambatan informasi yang mengakibatkan terkendalanya proses pelaporan hasil studi mahasiswa Undiksha. Hal ini merupakan salah satu hal yang menyebabkan persepsi dosen maupun mahasiswa dari segi ketepatan waktu informasi masih negatif sehingga terjadi kendala-kendala dalam proses pelaporan hasil studi mahasiswa Undiksha.

Dilihat dari sub indikator pengalaman, persepsi dosen dan mahasiswa terhadap sistem Informasi akademik dalam menunjang proses pelaporan hasil studi mahasiswa Undiksha masih negatif. Hal ini dikarenakan kurang cepatnya respon pelayana oleh pengelola sistem informasi akademik sehingga belum memenuhi harapan dosen maupun mahasiswa dalam proses pelaporan hasil studi mahasiswa Undiksha sehingga persepsi dosen dan mahasiswa Undiksha dilihat dari pengalaman masih negatif.

\section{SIMPULAN DAN SARAN Simpulan}

Berdasarkan penelitian yang dilakukan, maka dapat ditarik kesimpulan sebagai berikut. Pertama persepsi dosen terhadap sistem informasi akademik dalam menunjang proses pelaporan hasil studi mahasiswa Undiksha dilihat dari ketiga indikator dan keseluruhan sub indikator penelitian secara umum sudah menunjukan hasil yang baik atau positif, walaupun terdapat beberapa sub indikator yang menunjukan hasil negatif. Hal ini disebabkan karena masih terdapat sedikit kekurangan dalam sistem informasi akademik baik dalam pelayanan maupun penyajian informasi yang menunjang proses pelaporan hasil studi mahasiswa Undiksha. Kedua persepsi mahasiswa terhadap sistem informasi akademik dalam menunjang proses pelaporan hasil studi mahasiswa Undiksha dilihat dari ketiga indikator dan keseluruhan sub indikator penelitian secara umum sudah menunjukan hasil yang baik atau positif, walaupun terdapat beberpa sub indikator yang menunjukan hasil negatif. Hal ini dikarenakan kurang cepatnya pelayanan dan ketepatan waktu informasi yang disajikan sistem informasi akademik Undiksha.

\section{Saran}

Dari hasil penelitian diatas, saran yang dapat disampaikan sebagai berikut. Pertama diharapakan pihak pengelola sistem informasi akademik Undiksha lebih memahami harapan dosen dan meningkatkan pelayanan kepada dosen maupun mahasiswa, sehingga nantinya akan bisa lebih menunjang proses pelaporan hasil studi mahasiswa Undiksha. Kedua diharapakan pihak pengelola sistem informasi akademik Undiksha lebih meningkatkan kinerja sistem informasi akademik baik dalam penyajian informasi dan kecepatan akses informasi, sehingga nantinya bisa diakses oleh seluruh mahasiswa dan dosen tanpa mengakibatan kinerja sistem melambat.

\section{DAFT AR PUSTAKA}

Arikunto. 2006. Prosedur Penelitian, Suatu Pendekatan Paktik. Jakarta: PT Rineka Cipta.

Etin. 2011. Pengelolaan Sistem Informasi Akademik Perguruan Tinggi Berbasis Teknologi 
Informasi dan Komunikasi.

Sumedang.

Moch, Nazir. 2003. Metode Penelitian. Jakarta: Salemba Empat.

Muflih, Muhammad. 2006. Perilaku Konsumen Dalam Persepektif IImu Ekonomi Islam. Jakarta: Rajawali.

Rakhmat, Jalaluddin. 2007. Persepsi Dalam Proses Belajar Mengajar. Jakarta: Rajawali.

Robbins, S.P. 2002. Perilaku Organisasi Kontoversi Aplikasi Edisi Bahasa Indonesia. Jakarta: PT Prehallindo.

------. 2003. Perilaku Organisasi. Jilid I. Jakarta: PT INDEKS Kelompok Gramedia.

------. 2009. Perilaku Organisasi. Edisi 12. Jakarta: Salemba Empat.

Slameto. 2010. Belajar Dan FaktorFaktor Yang Mempengaruhinya. Jakarta: PT Rineka Cipta.

Sutarbi, Tata. 2012. Analisis Sistem Informasi. Yogyakarta: Andi.Suyanto. 2005. Pengantar Teknologi Informasi. Yogyakarta: Andi.

Wadi, Andi. 2006. Evaluasi Implementasi Program MBS Sebagai Upaya Peningkatan Kualitas Lulusan Pada SMKNegeri 1 Sukasade. Tesis tidak diterbitkan. Singaraja: Undiksha.

Walgito, Bimo. 2004. Pengantar Psikologi Umum. Yogyakarta: Andi.

Yakub. 2012. Pengantar Sistem Informasi. Yogyakarta: Graha IImu. 